\title{
Ruptured thoracic aortic aneurysm in patient with systemic lupus erythematosus
}

\author{
Aneurisma roto da aorta descendente em paciente com lúpus eritematoso sistêmico
}

Daniel Oliveira DE CONTI ${ }^{1}$, Ricardo Ribeiro DIAS ${ }^{2}$, Alfredo Inácio FIORELLI ${ }^{3}$, Noedir A. G. STOLF ${ }^{4}$

RBCCV 44205-1256

\begin{abstract}
Resumo
Paciente de 25 anos, do sexo feminino, portadora de lúpus eritematoso sistêmico, fazendo uso de corticoesteroide havia 19 anos, deu entrada em unidade de emergência com aneurisma roto de aorta torácica descendente. Foi submetida a tratamento endovascular com 2 stents, recebeu alta hospitalar no $13^{\circ}$ dia de pós-operatório, em boas condições de saúde. Três meses depois, retornou em choque hemorrágico secundário a hemorragia digestiva alta. Feito o diagnóstico de fístula aorto-esofágica, foi submetida à cirurgia aberta de emergência, indo a óbito durante o período pós-operatório.
\end{abstract}

Descritores: Aneurisma da aorta torácica. Lúpus eritematoso sistêmico. Stents.

\section{INTRODUCTION}

Systemic lupus erythematosus (SLE) is a chronic systemic inflammatory disease associated with the production of various auto antibodies and involvement of multiple organs, frequently associated with cardiovascular manifestations, but rarely complicated with aortic disease. It affects primarily young women, an age group usually free from atherosclerosis disease. Prolonged steroid therapy in an SLE patient may play a major role in accelerating

1. Médico Residente de Cirurgia Cardiovascular do InCor-HCFMUSP.

2. Doutor em Ciências pela USP; Médico Assistente da Unidade Cirúrgica de Cardiopatias Gerais.

3. Doutor em Ciências pela USP; Médico Assistente da Unidade Cirúrgica de Cardiopatias Gerais.

4. Professor Titular de Cirurgia Cardiovascular do InCor-HCFMUSP; Diretor Geral do InCor-HCFMUSP.

Work done at Heart Institute (InCor), University of São Paulo Medical School, São Paulo, SP, Brazil.

\section{Abstract}

It is reported a ruptured descending thoracic aortic aneurysm in a 25-year-old systemic lupus erythematosus woman who underwent 19 years steroid therapy. She was treated with 2 endovascular stent-grafts, discharged from hospital 13 days after the procedure in good health. Three months later she returned with hemorrhagic shock due to high digestive hemorrhage secondary to an aortic-esophageal fistula. She underwent to an open emergency surgery, and died during the post-operative period.

Descriptors: Aortic Aneurysm, Thoracic. Lupus Erythematosus, Systemic. Stents.

atherosclerosis [1], which could result in this patient's aortic aneurysm enlargement, possibly together with the primary aortic wall involvement due to SLE vasculitis. Few cases with this association have been described. The purposes of this report are to describe the rare association of descending thoracic aortic aneurysm (DTA), SLE disease, prolonged steroid therapy and the result of a short term outcome of an initially successful endovascular treatment that had to go to an emergency open surgery three months after the procedure.

Endereço para correspondência:

Ricardo R. Dias

Av. Dr. Enéas de Carvalho Aguiar, 44 bl 2 sala 13 - Cerqueira César São Paulo, SP, Brazil. Zip Code: 05403-000

E-mail: ricardo.dias@incor.usp.br 


\section{CASEREPORT}

A 25-year-old woman with SLE, diagnosed 19 years before, based on clinical and laboratory findings, had been medicated with cortisone since then. In 1990 she had a stroke with no sequels. She was frequently seen by nephrologists due to lupus nephritis and started the hemodialysis program in 1997. A few months later the renal function improved and she was kept without dialysis. In July 2007, she was admitted in the emergency room of our hospital, with thoracic pain that radiated to the interscapular region, associated with nauseas and vomits. The latest laboratorial data were of a no active disease The CT scan showed a ruptured DTA with maximum diameter of $8 \mathrm{~cm}$ (Figure 1), the proximal and distal neck measured approximately $26 \mathrm{~mm}$ and the distance between the diseased aorta and the left subclavian artery was $60 \mathrm{~mm}$.

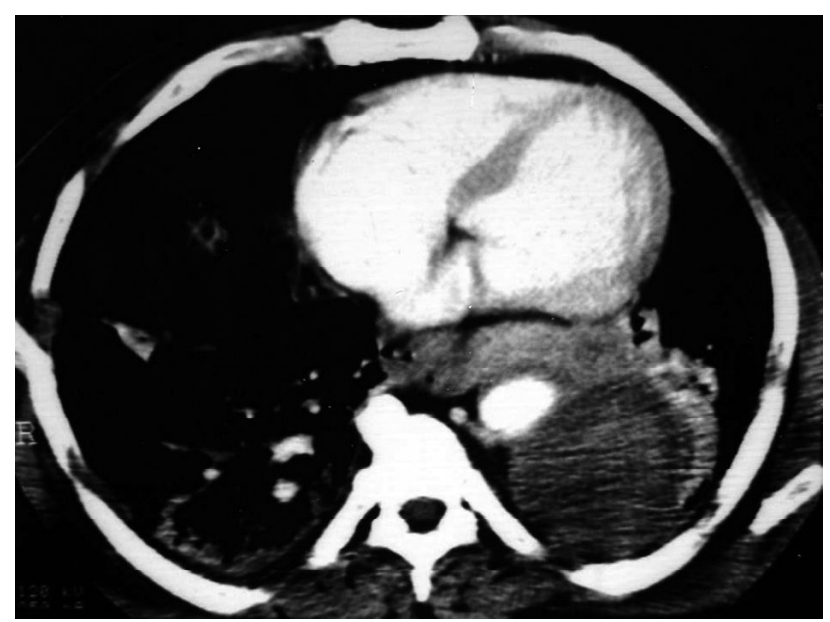

Fig. 1 - Computed tomography scan showing a ruptured aneurysm in the descending thoracic aorta

The patient was hemodynamically stable. She was immediately taken to the CAT LAB to be operated on by an experimented team in aorta endovascular procedures. Under general anesthesia, through the right femoral artery, a stentgraft (Medtronic ${ }^{\circledR}$ 32X32X200mm) was left at aortic zone III. Because of the long distance of the left subclavian artery, there was no need to cover the artery or to use a free flow stent-graft. The control angiographic study revealed a distal endoleak type I (Figure 2). For this reason, a secondary stent-graft (34X30X150mm) was used. It was used a balloon accommodation in the extremities as it was in the connection of the stents. The control aortography showed no endoleak and total exclusion of the aneurysm (Figure 3).

She remained in hospital for 13 days due to impairment of renal function and bronchopneumonia. A post-operative CT scan was scheduled for the $6^{\text {th }}$ month of the procedure. At three months of follow-up she returned to the emergency room of another hospital with a massive high digestive hemorrhage due to an aortic-esophageal fistula. Through the gastrointestinal endoscopy the stent-graft wall could be seen. The family told us she underwent to an open emergency surgery and died during the post-operative period (they could not give us details about the procedure).

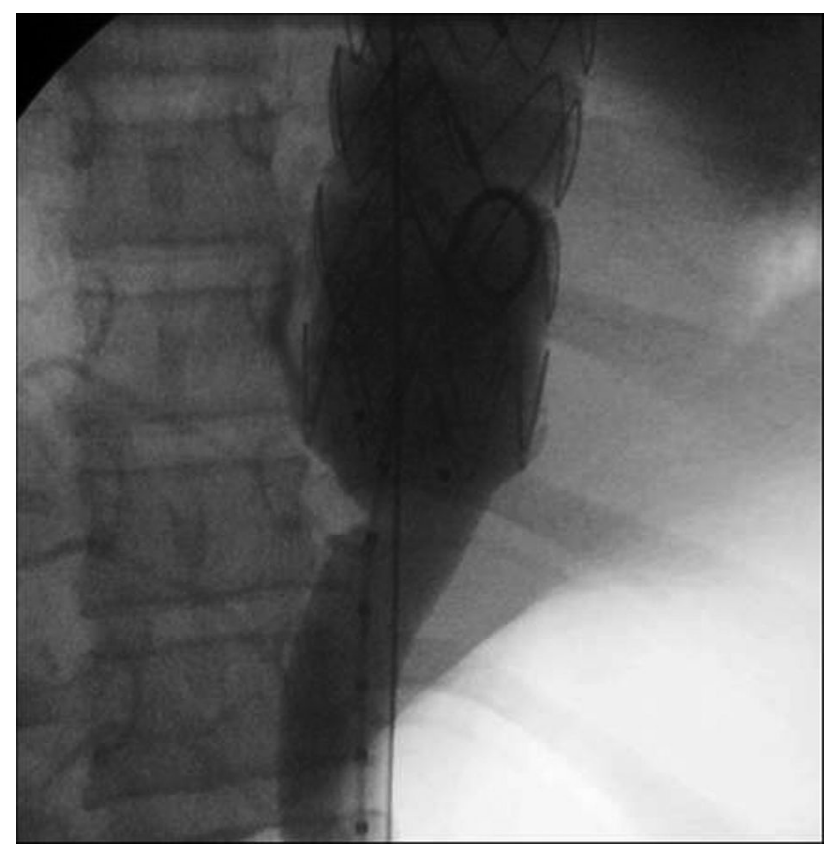

Fig. 2 - Stent-graft attached at aortic zone III showing a distal endoleak type I

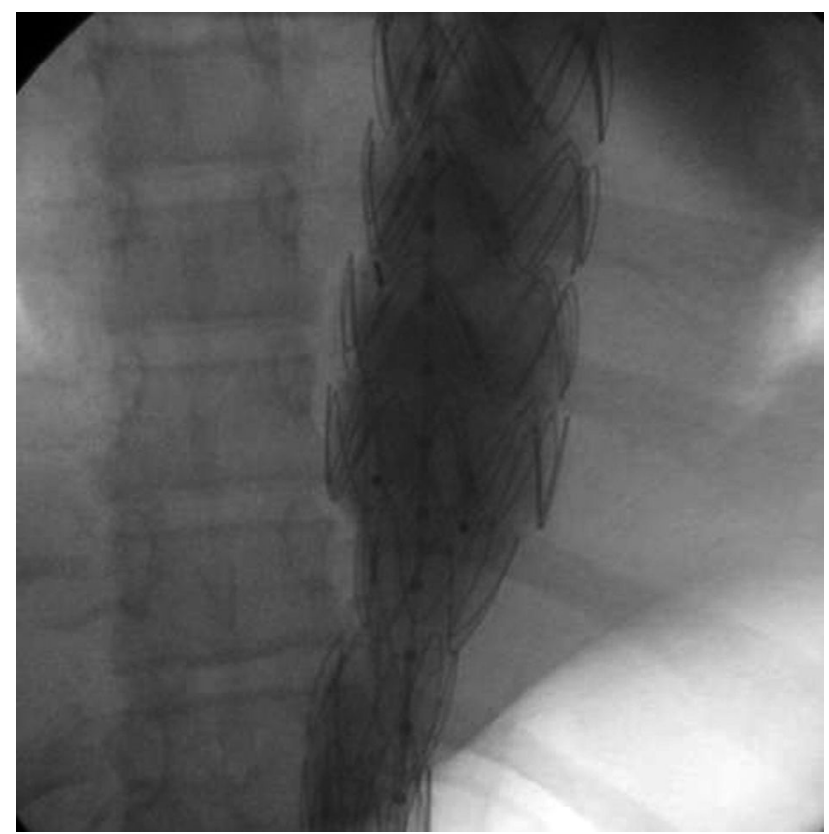

Fig. 3 - Control aortography showing no endoleak and total exclusion of the aneurismal sac 


\section{DISCUSSION}

The thoracic aortic aneurysms can be caused by atherosclerosis due to prolonged steroid therapy in systemic lupus erythematosus. Steroid therapy affects the connective tissue by inhibiting chondroitin sulfate and formation of granulation tissue and enhances the incidence rate of atherosclerosis [1]. Corticosteroids are atherogenic by unfavorably affecting body fat distribution, blood pressure and glucose metabolism leading to dyslipidemia, hypertension and diabetes mellitus [2]. The patient had been using cortisone for the last 19 years due to lupus nephritis, associated with oral hypotension medication. Aortic aneurysm is one of the unusual complications in patients with SLE [3]. According to Khan and Spiera [1], nine cases of patients with aortic aneurysm and SLE have been reported. The experience of Ohara et al. [4] from 429 patients operated on for abdominal aortic aneurysm shows that only five were associated with SLE.

In this case, the proximal portion of the descending aorta presented favorable to endograft attachment. It has been reported only two other cases of successful endovascular stent-grafting of DTA in SLE patients [5]. Little is known about long-term durability of either the device or the repair for patients with SLE disease [6].

The morbidity and mortality of the open repair of the ruptured DTA has been estimated as high as $20 \%$, with most estimating the risk of paraplegia at $4 \%$. Thoracic endoluminal stent grafting mortality ranged from $0 \%$ to $10 \%$, with the incidence of paraplegia between $0 \%$ and $12.5 \%$, mean $3.4 \%$. The occurrence of endoleak was between $0 \%$ and $25 \%$, with a mean of $10.6 \%$.

Although endografting does not eliminate all the risks of the open repair, it is associated with significantly smaller perioperative mortality and a shorter hospital stay. Moreover, the existence of active aortitis can weaken the suture line in the conventional procedure. Stent graft repair of the thoracic aorta appears to offer a feasible and safe alternative compared with conventional repair. Most reports of thoracic stent grafting offer promising results. However, these are generally retrospective single-center experiences. This less invasive approach may be of particular value for elderly patients or patients with coexisting conditions that would increase the risk of conventional treatment.

Transthoracic aortic surgery carries substantial risks of serious complications and mortality, which have diminished only slightly in recent years in spite of significant advances in perioperative care and surgical techniques. Longer follow-up is necessary to fully assess long-term results, specially for patients with vasculitis. In this reported case, the endovascular treatment little contributed to the postoperative survival of the patient.

\section{REFERENCES}

1. Khan AS, Spiera HJ. Association of aortic aneurysm in patients with systemic lupus erythematosus: a series of case reports and a review of the literature. J Rheumatol. 1998;25(10):201921.

2. Rhew EY, Ramsey-Goldman R. Premature atherosclerotic disease in systemic lupus erythematosus: role of inflammatory mechanisms. Autoimmun Rev. 2006;5(2):101-5.

3. Takagi H, Mori Y, Iwata H, Kimura M, Itokazu M, Shimokawa $\mathrm{K}$, et al. Nondissecting aneurysm of the thoracic aorta with arteritis in systemic lupus erythematosus. J Vasc Surg. 2002;35(4):801-4.

4. Ohara N, Miyata T, Kurata A, Oshiro H, Sato O, Shigematsu $\mathrm{H}$. Ten years' experience of aortic aneurysm associated with systemic lupus erythematosus. Eur J Vasc Endovasc Surg. 2000;19(3):288-93.

5. Kunihara T, Sasaki S, Nishibe T, Akimaro Kudo F, Shiiya N, Murashita T, et al. Successful endovascular stent-grafting for thoracic aortic aneurysms in systemic lupus erithematosus. Report of 2 cases and review of the literature. J Cardiovasc Surg (Torino). 2002;43(2):235-40.

6. Criado FJ, Clark NS, Barnatan MF. Stent graft repair in the aortic arch and descending thoracic aorta: a 4-year experience. J Vasc Surg. 2002;36(6):1121-8. 